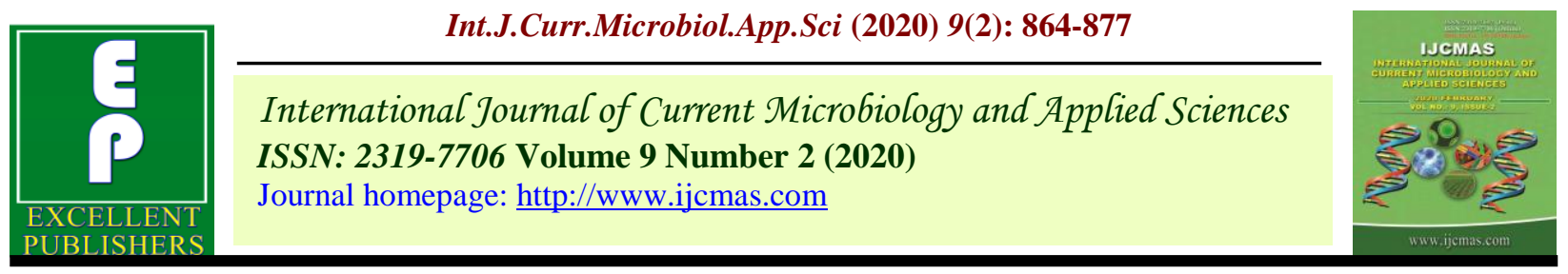

Original Research Article

https://doi.org/10.20546/ijcmas.2020.902.104

\title{
Impact of Irrigation and Mulch on Leaf Area Index, Yield and Water use Efficiency of Strawberry under Polyhouse
}

\author{
Sushanta Sarkar" and Supradip Sarkar \\ Department of Agricultural Meteorology \& Physics, Faculty of Agriculture, Bidhan Chandra \\ KrishiViswavidyalaya, Mohanpur, Nadia, 741252, West Bengal, India \\ *Corresponding author
}

\section{A B S T R A C T}

\section{Keywords}

Leaf area

index(LAI), Water

use efficiency, Drip

irrigation system,

Mulching, ETc,

IW/CPE

Article Info

Accepted:

08 January 2020

Available Online:

10 February 2020

\begin{abstract}
Since last few decades, fresh water availability is continuously declining against time and share of irrigation to it is also decreasing. However, under such situation we have to increase the income of the farmers. Efficient utilization of available water resources may be the best possible answer to it. Drip irrigation system is a water application method which can improve the water use efficiency. Reduction in evaporation loss through mulching also enhances water use efficiency. Considering these, a field experiment was carried out to assess sole and interactive effects of irrigation and mulch on leaf area index and fruit yield. There were four irrigation regimes viz. surface irrigation (SI) at IW/CPE=1 and three drip irrigation regimes at 1.0 ETc, 0.6 ETc and 0.8 ETc placed in main plots. Subplots were fitted with no mulch (NM), straw mulch (SM), black polyethylene mulch (BPM) and geo textile mulch (GTM). Irrespective of time highest value of LAI and yield were recorded under 1.0ETc and GTM. The same was lowest under SI and NM. LAI and yield posses' strong relationship, R2 value increased from 0.62 to 0.75 from first to third plucking period. Maximum WUE was noted under 0.6ETc-GTM combination and it was almost 10 times lower under SI-NM combination.
\end{abstract}

\section{Introduction}

Based on the precision irrigation principles, irrigation should be a precision activity that involves both the accurate assessment of the crop water requirements and the precise application of the exact amount of water at the right time, using hydraulic elements with high volumetric efficiencies and that allow spatially uniform applications. Drip irrigation systems have a greater potential for precision irrigation than other systems. They are easily controlled and are commonly automated.
Adoption of mulch means making a barrier between micro climate and soil surface. Mulching regulates the vapour pressure gradient at the soil surface and thus reducing the unproductive loss of soil water through transpiration. This way it conserve soil moisture in the root zone made more water available towards transpiration. It is a well known fact that use of mulch with drip system is a costly system and it is difficult for the poor farming community of India to adopt this system. To make it economically viable one has to select a crop having high demand 
in the market and can fetch good amount of net profit. Strawberry is such a crop which can be cultivated under drip system. Strawberry is highly demanded by both the fresh market and the food industry. The strawberry cultivation returns huge economic and social benefits to the region becoming in a strategic sector that generates more than 700 work days per ha per year. Mulching is commonly practiced in strawberry cultivation to keep the fruit clean and protect it from its contact with the soil to avoid fruit rot. This practice is also known for moderation of hydrothermal regime and increasing water use efficiency (Verma and Acharya, 1996).

In hills, SI is not suitable due to undulating topography, shallow and light textured soils with low water holding capacity and water resources. On the other hand drip irrigation is very popular in water scarcity areas as this system provides more frequent, precise and direct application of water in small quantities in the root zone. It had shown 15-20\% increase in yield, more saving in water and energy, better water supply and less rotting of strawberry under drip irrigation (Childers et al., 1995).Work carried out earlier on drip irrigation and mulching in fruits and vegetables gave encouraging results in terms of yield and WUE (Raina et al., 1999; Singh et al., 1999).

\section{Materials and Methods}

\section{Details of the experiment}

A field experiment was carried out during the post rainy season (November to March) of 2015-162016-17 at Central Research Farm, Gayeshpur, B.C.K.V., Nadia, West Bengal, India $\left(22^{\circ} 58^{\prime} \mathrm{N}\right.$ latitude, $88^{\circ} 31^{\prime} \mathrm{E}$ longitude and at an elevation of 9.75 meters above mean sea level) under poly house condition. There were four irrigation regimes viz. surface irrigation $(\mathrm{SI})$ at $\mathrm{IW} / \mathrm{CPE}=1$ and three drip irrigation regimes at $1.0 \mathrm{ET}_{\mathrm{c}}, 0.6 \mathrm{ET}_{\mathrm{c}}$ and 0.8 $\mathrm{ET}_{\mathrm{c}}$, placed in main plots. Subplots were fitted with no mulch (NM), straw mulch (SM), black polyethylene mulch (BPM) and geo textile mulch (GTM).All treatment combinations were replicated thrice.

\section{Climatic status}

The climate of this region is humid tropics, summer is hot and winter is moderate. May is generally the hottest month of the year. In general, south-west monsoon breaks in the $1^{\text {st }}$ week of June and ceases during $3^{\text {rd }}$ week of October. Gayeshpur receives an average annual rainfall of $1600 \mathrm{~mm}$ out of which 1300 $\mathrm{mm}$ occurs during monsoon season. The average temperature values lies between $25^{\circ} \mathrm{t}$ - $36^{\circ} \mathrm{C}$ in summer and in winter it remains within $10^{\circ} \mathrm{C}-25^{\circ} \mathrm{C}$.

\section{Field preparation}

The experiment was carried out in a protected condition. The area under the protected condition was cleaned and ploughed by two crosswise passes of tractor drawn spring type cultivators followed by surface levelling with a horizontal wooden beam (indigenous leveller).

\section{Plant protection}

Initially the plants shown dryness and observed red termites in soil. To make free from red termites, neem soil and chloropyriphos of recommended dose was sprayed two times. To protect from fungal attack Blitox@0.2\% and Bavistin @ 0.2\% were sprayed alternatively at the initial stage of growth.

\section{Fertilizer application}

At the time of land preparation farm yard manure was applied @ $2 \mathrm{mg} \mathrm{ha}^{-1}$. 
Recommended inorganic fertilizers i.e. $\mathrm{N}$, $\mathrm{P}_{2} \mathrm{O}_{5}$ and $\mathrm{K}_{2} \mathrm{O}$ were applied @ 120: 60: $40 \mathrm{Kg}$ ha $^{-1}$.

\section{Surface irrigation}

Surface irrigation scheduling was based on $\mathrm{IW} / \mathrm{CPE}=1$. When cumulative pan evaporation value reached the desired level $(30 \mathrm{~mm})$ the crop was irrigated.

\section{Drip irrigation}

Drip irrigation scheduling was based on the replenishment of the loss of evapotranspiration takes place in between two irrigation dates. In this study $\mathrm{ET}_{\mathrm{c}}(\mathrm{mm} / \mathrm{d})$ was computed by multiplying the values of pan evaporation $\left(\mathrm{E}_{\mathrm{pan}}\right)$ during that period with pan $\left(\mathrm{K}_{\mathrm{p}}\right)$ and crop $\left(\mathrm{K}_{\mathrm{c}}\right)$ coefficient values as:

$\mathrm{ET}_{\mathrm{c}}=\mathrm{E}_{\mathrm{pan}} * \mathrm{~K}_{\mathrm{p}} * \mathrm{~K}_{\mathrm{c}}$

A USWB class A pan evaporimeter was used to measure the daily values of $E_{\text {pan }}$ for each standard week during the cropping period. Values of $\mathrm{K}_{\mathrm{p}}$ was computed as per table 5 of FAO manual No. 56 (Allen et al., 1998) and it was 0.8 during the entire cropping period. Discharge rate of the dripper was $0.1351 / \mathrm{min}$ at an operational pressure of 4 atmospheres. This information was used for calculating the volume of water to be discharged as per irrigation schedule. Water discharge amount gradually increased with the increase in atmospheric evaporative demand and advancement of crop growth.

\section{Leaf area index (LAI) calculation}

Leaf area index (LAI) was measured at 30 days interval starting from 30 DAP. The leaf area index was calculated by dividing the total leaf area with the corresponding ground area as suggested by Watson (1947).
Leaf area index was calculated using the following formula.

LAI $=$ Total leaf area $\left(\mathrm{cm}^{2}\right) /$ Unit ground area $\left(\mathrm{cm}^{2}\right)$

\section{Estimation of actual evapotranspiration by water balance method}

Actual evapotranspiration was computed as:

$\mathrm{AET}=\mathrm{P}+\mathrm{I}+\mathrm{C}-\mathrm{D} \pm \Delta \mathrm{SWS}$

Where, $\mathrm{P}$ is precipitation $(\mathrm{mm}), \mathrm{I}$ is total irrigation water applied $(\mathrm{mm}), \mathrm{C}$ is capillary contribution $(\mathrm{mm}), \mathrm{D}$ is vertical drainage $(\mathrm{mm})$ and $\triangle \mathrm{SWS}$ is depletion in soil water storage $(\mathrm{mm})$.

\section{Water use efficiency}

Water use efficiency (WUE, $\mathrm{kg} \mathrm{m}^{-3}$ ) of the test crop was calculated following Huang et al., (2004) as:

$\mathrm{WUE}=\mathrm{k} \times(\mathrm{Y} / \mathrm{AET})$

where $\mathrm{k}$ is a unit constant equal to 100 when fruit yield (Y) and seasonal AET expressed in $\mathrm{q} / \mathrm{ha}$ and $\mathrm{mm}$ respectively.

\section{Statistical analysis}

For interpretation of the effect of different treatments all the records data on leaf area index and fruit yield were analyzed statistically. The comparison between treatment means was tested for significance by $\mathrm{F}$ test. For the data in which the treatment and interaction effects were significant the critical difference (CD) and standard error of mean (SEm \pm ) were calculated at 5 percentlevel of significance. The experimental data were analyzed by using standard procedure of split plot design (Panse and Sukhatme, 1967). 


\section{Finding}

\section{Effectof irrigation and mulch on leaf area index (LAI)}

Leaf area index is an important parameter, which monitors the different components of photosynthetic active radiation as well as actual evapotranspiration takes place from any crop field. It also used to compute the extinction coefficient value from any crop field. In the present study leaf area index values were measured on 30, 60, 90 and 120 days after transplanting (DAT).

Irrespective of irrigation regimes and mulch management it has been observed that lowest value of LAI was recorded on first observation date (30 DAT). Under different irrigation regimes (Table 1) it has been observed that during 30-60 DAT magnitude of mean LAI increased by 81, 83, 119 and 86 percent respectively under $1.0 \mathrm{ET}_{\mathrm{c}}, 0.8 \mathrm{ET}_{\mathrm{c}}$, $0.6 \mathrm{ET}_{\mathrm{c}}$ and surface irrigation. During 60-90 DAT the increment rates were 64, 56, 18 and 18 percent under those above mentioned regimes. This data base showed rapid vegetative growth during (30-60 DAT) early vegetative phase of the crop. The increment trend lowers down at mid vegetative phase (60-90 DAT). However in the last vegetative phase a reverse trend was observed where magnitude of mean LAI decreased by 26,21 , 6 and 7 percent under above mention irrigation regimes with the advancement of cropping period from 90-128 DAT. Senesces of old leaves is the reason behind the decrease in the magnitude of LAI at 128 DAT over 90 DAT. It has been observed that $100 \%$ compensate of atmospheric evaporative demand (1.0 $\mathrm{ET}_{\mathrm{c}}$ ) resulted in highest level of LAI of the crop at all the observation date (Table 1). The same gradually decrease from $1.0 \mathrm{ET}_{\mathrm{c}}$ to $0.6 \mathrm{ET}_{\mathrm{c}}$ to $0.8 \mathrm{ET}_{\mathrm{c}}$. Interestingly it has been noted that application of 2 to 3 fold higher irrigation water under surface irrigation (SI) system resulted in lowest value of LAI. Such data established the efficiency of drip system over surface irrigation system. In all the observation dated impact of moisture regimes found statistically significant.

The temporal variation of LAI under different mulch management showed similar trend like that of under different irrigation regimes. Greater moisture loss through evaporation from the soil surface resulted in lowest value (1.01 to 2.1) of LAI under no mulch environment. On 30 DAT geo textile mulch (GTM) resulted in maximum (1.33) LAI. This was reduced by 19 and 17 percent respectively under black polyethylene mulch (BPM) and straw mulch (SM) management. In other observation dates similar trend was recorded. However the difference in LAI values among the mulch treatments increased from 30-90 DAT through 60 DAT. In all the observation dates impact of mulch was found statistically significant. Fig 1 and fig 2 show variation in LAI due to irrigation regimes or mulch management in most prominent impact on 90 DAT followed by 120, 60 and 30 DAT respectively.

Table 3 showed intensive effects of 16 treatment combinations on LAI was statistically significant on 90 and 120 DAT. Minimum value (0.68-1.15) was recorded under surface irrigation with no mulch condition. In contrast 1.0ET $\mathrm{E}_{\mathrm{c}}-\mathrm{GTM}$ combination reflected highest value of LAI (1.78-5.68).

\section{Effect of irrigation and mulch on fruit yield}

Strawberry is a crop where multi plucking of fruits is a common practice rather than a single harvest situation as found in field crops like rice, wheat etc. Plucking of fruits stared from 30 DAT and it continues up to final harvest. The yield data of fruits were clubbed 
into three ranges of DAT as 60-80, 81-110, and 111-128. Irrespective of irrigation regimes maximum fruit yield (mean of two years)was recorded during 81-110 DAT followed by 111-128 DAT and 60-80 DAT (Table 4). Like LAI during first phase maximum fruit yield was recorded under $1.0 \mathrm{ET}_{\mathrm{c}}$. This was reduced by 3 and $16 \%$ respectively under $0.8 \quad \mathrm{ET}_{\mathrm{c}}$ and $0.6 \mathrm{ET}_{\mathrm{c}}$. However very high reduction $(107 \%)$ in fruit yield noted when the comparison was made between $1.0 \mathrm{ET}_{\mathrm{c}}$ and surface irrigation. Variation on fruit yield under different irrigation regimes showed similar trend in second and third plucking like that of first one.

Temporal variation of fruit yield under different mulches showed similar trend like that of irrigation regimes. However the degree of variation was minimum under no mulch and maximum under geo textile mulch. Irrespective of fruit plucking stages, lowest fruit yield was recorded under no mulch environment (Table 5). Both straw and black polyethylene mulch resulted in increased fruit yield over no-mulched condition.

On phase wise fruit production, irrigation regimes showed similar trend like that of LAI (Fig 3). It is clear from figure 4 that impact of mulch on fruit yield do not follow similar trend like that of LAI. Highest fruit yield was recorded on GTM followed by SM then BPM and lowest one under NM. Both irrigation regimes and mulch resulted in statistically significant on both fruit yield at each plucking stage.

Among the 16 treatment combinations SI-NM showed lowest fruit yield throughout the entire cropping period. In contrast $1.0 \mathrm{ET}_{\mathrm{c}^{-}}$ GTM combination resulted in highest fruit yield and this was 3-4 times higher over the fruit yield obtained under SI-NM combination (Table 6). During the entire cropping period variation of fruit yield under different treatment combination found statistically significant.

In any study of fruit crops total fruit yield is also an important factors considering the total yield of strawberry under different irrigation regimes as well as mulch management has been presented in a two way format table (Table 7). In total 289q strawberry yield (mean of two years) was recorded under 1.0 $\mathrm{ET}_{\mathrm{c}}$. The same decreased by 6 and $14 \%$ respectively under $0.8 \mathrm{ET}_{\mathrm{c}}$ and $0.6 \mathrm{ET}_{\mathrm{c}}$ under drip irrigation regimes. Crop yield reduced $105 \%$ under surface irrigation regimes over $1.0 \mathrm{ET}_{\mathrm{c}}$. Total fruit yield recorded highest value 347q under GTM (Table 7) and it reduced by 22 and $54 \%$ respectively under SM and BPM. Under no mulch situation only $115 q$ fruit yield was recorded and this was $1 / 3$ rd of the fruit yield that was obtained under GTM.

The increased yield under drip irrigation might be due to near optimum soil hydrothermal conditions in the root zone throughout the growing season due to better water utilization (Manfrinato, 1974), higher uptake of nutrients (Bafna et al., 1993) and excellent soil-water-air relationships with higher oxygen concentration in root zone (Gornat et al., 1973).

\section{LAI-fruit yield relationship}

LAI data of any crop canopy provides the information in advance about the probable economic yield of any crop. Considering this an attempt has been made to assess the relationship between LAI and fruit yield for each plucking stage as well as for the total yield.

During first plucking period magnitude of LAI was ranged in between 1.57 to 2.61. During that period fruit yield was within the 
range of 11 to $34 \mathrm{q} /$ ha. Figure 5 shows the existence of a steady positive relationship between LAI and fruit yield with a moderately strong $\mathrm{R}^{2}(0.62)$ value. The relationship was much stronger $\left(\mathrm{R}^{2}=0.66\right)$ when it was assessed for the second plucking period (Figure 6). Relationship between LAI and fruit yield attained highest $\mathrm{R}^{2}$ value $(0.75)$ during third plucking period (Fig. 7). An attempt has also been made to establish the influence of LAI on total fruit yield (Fig. 8). Pulled data presented in figure 8 showed a steady linear relationship between LAI and fruit yield with $R^{2}$ value of 0.61 . In figure 8 as a wide range of data being used to draw the relationship the $\mathrm{R}^{2}$ value was at the lowest level.

\section{Effect of irrigation and mulch on water use efficiency (WUE, kg/m³}

Water is becoming a scarce commodity day by day. At present availability of fresh water is sowing a decline trend as well as share of irrigation on it also decreases. Therefore the target of any water management research is to enhance the use efficiency level of irrigation water. WUE also termed as crop water productivity is an appropriate index to quantify the efficiency of irrigation water applied for crop production. In the present study an average lowest $\left(5.5 \mathrm{~kg} / \mathrm{m}^{3}\right)$ WUE value recorded under surface irrigation with 3 cm depth of irrigation (Table 9). It is a well known fact to all of us that application of water through drip markedly improves use efficiency level of irrigation water (Tekinel et al., 1989). In the present study when drip irrigation regimes fixed at $1.0 \mathrm{ET}_{\mathrm{c}}$ level on average WUE level was $25.77 \mathrm{~kg} / \mathrm{m}^{3}$. The same enhanced to $27.82 \mathrm{~kg} / \mathrm{m}^{3}$ when drip irrigation regime was fixed at $0.8 \mathrm{ET}_{\mathrm{c}}$. In general it has been observed that application of lower amount of water, in general, increase the magnitude of WUE. In support of this concept, in the present study it has been recorded $36.42 \mathrm{~kg} / \mathrm{m}^{3}$ WUE level when irrigation was fixed at $0.6 \mathrm{ET}_{\mathrm{c}}$ level.

In the present study it has been observed that irrespective of mulch managements lowest value of WUE obtained under NM condition. The highest value of WUE was noted when GTM was used as mulch material. The increment of WUE through adoption of GTM over NM condition enhanced the WUE level WUE level by 55, 266, 327 and 197.5 percent respectively under $\mathrm{SI}, 0.6 \mathrm{ET}_{\mathrm{c}}, 0.8 \mathrm{ET}_{\mathrm{c}}$ and 1.0 $\mathrm{ET}_{\mathrm{c}}$ irrigation regimes. Under all the irrigation regimes $\mathrm{SM}$ helps in recording second highest WUE value and it was in the range 6.0 to $43.9 \mathrm{~kg} / \mathrm{m}^{3}$. We all know BPM is capable in reducing the evaporation loss to the maximum possible extent but it attain $3^{\text {rd }}$ position so far the WUE value is concerned.

\section{Yield-WUE relationship}

In the present study under drip less amount of water was irrigated over surface irrigation. However, the yield obtained under different drip regimes was higher than the yield recorded under surface irrigation. Besides, under different mulches total amount of AET was at a lower level over the no mulch condition. In contrast yield was more under mulched plots than no mulch one. Due to these reasons, AET-Yield relationship was not positive as usually happened. Therefore AET-Yield relationship has not been worked out in this experiment.

In the present study it has been found both yield and water use efficiency (WUE) were at a higher level under drip irrigation system than that of the surface irrigation. Therefore an attempt was made to establish a relationship between fruit yield of strawberry to the WUE value of the crop (Fig. 9). Present data base showed a strong linear relationship value. A high $R^{2}(0.78)$ value is exist in this relationship. 
Table.1 Impact of irrigation regimes on temporal variation in leaf area index of strawberry during 2015-16 and 2016-17 (Mean of two years)

\begin{tabular}{|c|c|c|c|c|}
\hline Irrigation Regimes & \multicolumn{4}{|c|}{ Days After Transplanting } \\
\cline { 2 - 5 } & 30 & 60 & 90 & 120 \\
\hline $\mathbf{1 . 0 ~ E T}_{\mathbf{C}}$ & 1.44 & 2.61 & 4.29 & 3.36 \\
\hline $\mathbf{0 . 8 ~ E T ~}_{\mathbf{C}}$ & 1.29 & 2.37 & 3.74 & 3.09 \\
\hline $\mathbf{0 . 6 ~ E T}_{\mathbf{C}}$ & 1.01 & 2.22 & 2.62 & 2.48 \\
\hline Surface Irrigation & 0.84 & 1.57 & 1.85 & 1.73 \\
\hline S.Em. ( $\mathbf{(})$ & $\mathbf{0 . 0 7 6}$ & $\mathbf{0 . 0 4 3}$ & $\mathbf{0 . 0 3 5}$ & $\mathbf{0 . 0 4 1}$ \\
\hline CD(p=0.05) & $\mathbf{0 . 2 6 8}$ & $\mathbf{1 . 1 5 2}$ & $\mathbf{0 . 1 2 5}$ & $\mathbf{0 . 1 4 4}$ \\
\hline
\end{tabular}

Values presented in the table are average over mulches

Table.2 Impact of mulches on temporal variation in leaf area index of strawberry during 2015-16 and 2016-17 (Mean of two years)

\begin{tabular}{|l|c|c|c|c|}
\hline \multirow{2}{*}{ Irrigation Regimes } & \multicolumn{4}{|c|}{ Days After Transplanting } \\
\cline { 2 - 5 } & 30 & 60 & 90 & 120 \\
\hline NM & 1.01 & 1.8 & 2.1 & 2 \\
\hline SM & 1.14 & 2.11 & 2.72 & 2.54 \\
\hline BPM & 1.12 & 2.27 & 3.34 & 2.52 \\
\hline GTM & 1.33 & 2.6 & 4.35 & 3.6 \\
\hline S.Em. ( $\mathbf{( )}$ & $\mathbf{0 . 0 6 9}$ & $\mathbf{0 . 0 6 4}$ & $\mathbf{0 . 0 3 5}$ & $\mathbf{0 . 0 5 4}$ \\
\hline CD(p=0.05) & $\mathbf{0 . 2 0 2}$ & $\mathbf{0 . 1 8 9}$ & $\mathbf{0 . 1 0 4}$ & $\mathbf{0 . 1 6}$ \\
\hline
\end{tabular}

Values presented in the table are average over irrigation regimes

Table.3 Interactive effect of irrigation regimes and mulches on leaf area index values of strawberry during the crop growing period during 2015-16 and 2016-17 (Mean of two years)

\begin{tabular}{|c|c|c|c|c|}
\hline \multirow{2}{*}{$\begin{array}{l}\text { Treatment } \\
\text { combinations }\end{array}$} & \multicolumn{4}{|c|}{ Days after transplanting } \\
\hline & 30 & 60 & 90 & 120 \\
\hline $1^{1.0 E T} T_{c}-N M$ & 1.19 & 2.11 & 3.01 & 2.59 \\
\hline $1.0 \mathrm{ET}_{\mathrm{c}}-\mathrm{SM}$ & 1.35 & 2.56 & 3.89 & 3.29 \\
\hline $1.0 E T_{c-B P M}$ & 1.45 & 2.77 & 4.59 & 3.16 \\
\hline $1.0 E T_{c}-G T M$ & 1.78 & 2.99 & 5.68 & 4.4 \\
\hline $0.8 E T_{c}-N M$ & 1.17 & 2.15 & 2.22 & 2.31 \\
\hline $0.8 \mathrm{ET}_{\mathrm{c}}-\mathrm{SM}$ & 1.41 & 2.52 & 3.14 & 3.13 \\
\hline $0.8 E T_{c}-B P M$ & 1.04 & 2.15 & 3.98 & 2.49 \\
\hline $0.8 E T_{c}-G T M$ & 1.55 & 2.68 & 5.62 & 4.41 \\
\hline $0.6 \mathrm{ET}_{\mathrm{c}}-\mathrm{NM}$ & 0.98 & 1.88 & 2.01 & 1.98 \\
\hline $0.6 \mathrm{ET}_{\mathrm{c}}-\mathrm{SM}$ & 1 & 2.09 & 2.39 & 2.31 \\
\hline $0.6 E T_{c-B P M}$ & 1.06 & 2.27 & 2.78 & 2.5 \\
\hline $0.6 \mathrm{ET}_{\mathrm{c}}-\mathrm{GTM}$ & 0.99 & 2.66 & 3.3 & 3.13 \\
\hline SI-NM & 0.68 & 1.05 & 1.15 & 1.13 \\
\hline SI-SM & 0.78 & 1.28 & 1.45 & 1.41 \\
\hline SI-BPM & 0.93 & 1.88 & 2.01 & 1.91 \\
\hline SI-GTM & 0.98 & 2.06 & 2.78 & 2.47 \\
\hline S.Em. ( $( \pm)$ & 0.152 & 0.086 & 0.071 & 0.082 \\
\hline $\mathrm{CD}(\mathrm{p}=0.05)$ & NS* & NS & 0.218 & 0.33 \\
\hline
\end{tabular}

*Non Significant 
Table.4 Impact of irrigation regimes on periodical fruit yield (q/ha) of strawberry during 201516 and 2016-17 (Mean of two years)

\begin{tabular}{|l|c|c|c|}
\hline \multirow{2}{*}{ Irrigation Regimes } & \multicolumn{3}{|c|}{ Different Plucking periods (DAT) } \\
\cline { 2 - 4 } & 60 to 80 & 81 to 110 & 111 to 128 \\
\hline $\mathbf{1 . 0 ~ E T}_{\mathbf{c}}$ & 29 & 174 & 95 \\
\hline $\mathbf{0 . 8 ~ E T}_{\mathbf{c}}$ & 28 & 163 & 89 \\
\hline $\mathbf{0 . 6 ~ E T}_{\mathbf{c}}$ & 25 & 147 & 81 \\
\hline Surface Irrigation & 14 & 82 & 45 \\
\hline S.Em. ( $\mathbf{(})$ & $\mathbf{0 . 0 6 4}$ & $\mathbf{0 . 0 3}$ & $\mathbf{0 . 0 6 5}$ \\
\hline CD(p=0.05) & $\mathbf{0 . 2 2 6}$ & $\mathbf{0 . 1 0 6}$ & $\mathbf{0 . 2 2 8}$ \\
\hline
\end{tabular}

Data presented in the table are averaged over mulching

Table.5 Impact of mulches on periodical fruit yield (q/ha) of strawberry during 2015-16 and 2016-17 (Mean of two years)

\begin{tabular}{|l|c|c|c|}
\hline \multirow{2}{*}{ Irrigation Regimes } & \multicolumn{3}{|c|}{ Different Plucking periods (DAT) } \\
\cline { 2 - 4 } & 60 to 80 & 81 to 110 & 111 to 128 \\
\hline NM & 11 & 67 & 37 \\
\hline SM & 28 & 166 & 91 \\
\hline BPM & 22 & 131 & 72 \\
\hline GTM & 34 & 202 & 111 \\
\hline S.Em. $(\mathbf{\pm})$ & $\mathbf{0 . 3 3 5}$ & $\mathbf{0 . 3 3 6}$ & $\mathbf{0 . 3 3 6}$ \\
\hline CD(p=0.05) & $\mathbf{0 . 9 8 5}$ & $\mathbf{0 . 9 8 8}$ & $\mathbf{0 . 9 8 6}$ \\
\hline
\end{tabular}

Values presented in the table are average over irrigation regimes

Table.6 Interactive effect of irrigation regimes and mulches on periodical fruit yield (q/ha) of strawberry during 2015-16 and 2016-17 (Mean of two years)

\begin{tabular}{|c|c|c|c|}
\hline \multirow[t]{2}{*}{ Treatment combinations } & \multicolumn{3}{|c|}{ Different Plucking periods (DAP) } \\
\hline & 60 to 80 & 81 to 110 & 111 to 128 \\
\hline $1.0 E T_{c}-N M$ & 14 & 83 & 46 \\
\hline $1.0 \mathrm{ET}_{\mathrm{c}}-\mathrm{SM}$ & 33 & 194 & 107 \\
\hline $1.0 \mathrm{ET}_{\mathrm{c}}-\mathrm{BPM}$ & 28 & 168 & 92 \\
\hline $1.0 E T_{c^{-}}-$GTM & 43 & 252 & 138 \\
\hline $0.8 E T_{c}-N M$ & 10 & 59 & 32 \\
\hline $\mathrm{O.8ET}_{\mathrm{c}}-\mathrm{SM}$ & 34 & 201 & 110 \\
\hline${ }_{0.8 E T_{c}-B P M}$ & 24 & 139 & 76 \\
\hline $\mathrm{O.8ET}_{\mathrm{c}^{-}}$GTM & 42 & 249 & 137 \\
\hline $0.6 E T_{c-N M}$ & 10 & 58 & 32 \\
\hline $0.6 \mathrm{ET}_{\mathrm{c}}-\mathrm{SM}$ & 30 & 178 & 98 \\
\hline $0.6 \mathrm{ET}_{\mathrm{c}}-\mathrm{BPM}$ & 24 & 140 & 77 \\
\hline $0.6 \mathrm{ET}_{\mathrm{c}^{-}}-\mathrm{GTM}$ & 36 & 214 & 117 \\
\hline SI-NM & 11 & 67 & 37 \\
\hline SI-SM & 15 & 90 & 49 \\
\hline SI-BPM & 13 & 79 & 43 \\
\hline SI-GTM & 16 & 94 & 51 \\
\hline S.Em. $( \pm)$ & 0.128 & 0.06 & 0.129 \\
\hline $\mathrm{CD}(\mathrm{p}=0.05)$ & 1.947 & 1.976 & 1.976 \\
\hline
\end{tabular}


Table.7 Interactive effect of irrigation regimes and mulches on total fruit yield $(\mathrm{q} / \mathrm{ha})$ of strawberry during 2015-16 and 2016-17 (Mean of two years)

\begin{tabular}{|c|c|c|c|c|c|}
\hline \multirow{2}{*}{$\begin{array}{l}\text { Irrigation } \\
\text { regimes }\end{array}$} & \multicolumn{4}{|c|}{ Mulching } & \multirow[t]{2}{*}{ Mean } \\
\hline & NM & SM & BPM & GTM & \\
\hline $1.0 \mathrm{ET}_{\mathrm{c}}$ & 143 & 334 & 288 & 433 & 289 \\
\hline $0.8 \mathrm{ET}_{\mathrm{c}}$ & 101 & 345 & 239 & 428 & 279 \\
\hline $0.6 \mathrm{ET}_{\mathrm{c}}$ & 100 & 305 & 240 & 367 & 253 \\
\hline Surface irrigation & 115 & 154 & 135 & 161 & 141 \\
\hline \multirow[t]{2}{*}{ Mean } & 115 & 284 & 225 & 347 & \\
\hline & S.Em. ( \pm$)$ & $\mathrm{CD}(\mathrm{p}=0.05)$ & & & \\
\hline Irrigation & 0.165 & 0.582 & & & \\
\hline Mulching & 0.335 & 0.982 & & & \\
\hline I $\mathbf{x}$ M & 0.330 & 1.994 & & & \\
\hline
\end{tabular}

Table.8 Summary table of regression equation between LAI and fruit yield with corresponding $\mathrm{R}^{2}$ value during 2015-16 and 2016-17 (Mean of two years)

\begin{tabular}{|l|c|c|}
\hline Status & Regression equation & $\mathbf{R}^{\mathbf{2}}$ \\
\hline First plucking period & $\mathrm{Y}=17.4 \mathrm{X}-14.22$ & 0.62 \\
\hline Second plucking period & $\mathrm{Y}=40.95 \mathrm{X}+13.46$ & 0.66 \\
\hline Third plucking period & $\mathrm{Y}=35.33 \mathrm{X}-16.37$ & 0.75 \\
\hline Total & $\mathrm{Y}=49.38 \mathrm{X}-50.63$ & 0.61 \\
\hline
\end{tabular}

Table.9 Interactive effects of irrigation regimes and mulches on actual evapotranspiration and water use efficiency during 2015-16 and 2016-17 (Mean of two years)

\begin{tabular}{|c|c|c|c|c|c|}
\hline $\begin{array}{l}\text { Treatment } \\
\text { combinations }\end{array}$ & $\begin{array}{l}\text { AET } \\
(\mathbf{m m})\end{array}$ & $\begin{array}{c}\text { WUE (kg } \\
\left.\mathbf{m}^{-3}\right)\end{array}$ & $\begin{array}{l}\text { Treatment } \\
\text { combinations }\end{array}$ & $\begin{array}{l}\text { AET } \\
(\mathbf{m m})\end{array}$ & $\begin{array}{c}\text { WUE } \\
\left(\mathrm{kg} \mathrm{m}^{-3}\right)\end{array}$ \\
\hline $1.0 \mathrm{ET}_{\mathrm{c}}-\mathrm{NM}$ & 116 & 1.24 & $0.6 \mathrm{ET}_{\mathrm{c}}-\mathrm{NM}$ & 69.6 & 1.44 \\
\hline $1.0 \mathrm{ET}_{\mathrm{c}}-\mathrm{SM}$ & 116 & 2.88 & $0.6 \mathrm{ET}_{\mathrm{c}}-\mathrm{SM}$ & 69.6 & 4.39 \\
\hline $1.0 \mathrm{ET}_{\mathrm{c}}-\mathrm{BPM}$ & 116 & 2.48 & $0.6 \mathrm{ET}_{\mathrm{C}}-\mathrm{BPM}$ & 69.6 & 3.46 \\
\hline $1.0 \mathrm{ET}_{\mathrm{c}}-\mathrm{GTM}$ & 116 & 3.69 & $0.6 \mathrm{ET}_{\mathrm{c}}-\mathrm{GTM}$ & 69.6 & 5.28 \\
\hline $0.8 \mathrm{ET}_{\mathrm{c}}-\mathrm{NM}$ & 92.8 & 1.09 & SI-NM & 281.2 & 0.41 \\
\hline $0.8 \mathrm{ET}_{\mathrm{c}}-\mathrm{SM}$ & 92.8 & 3.71 & SI-SM & 255.4 & 0.6 \\
\hline $0.8 \mathrm{ET}_{\mathrm{c}}-\mathrm{BPM}$ & 92.8 & 2.57 & SI-BPM & 240.5 & 0.56 \\
\hline $0.8 \mathrm{ET}_{\mathrm{c}}-\mathrm{GTM}$ & 92.8 & 4.66 & SI-GTM & 255.7 & 0.63 \\
\hline
\end{tabular}


Fig.1 Temporal changes in leaf area index under varying irrigation regimes (Values presented in figure are averaged over mulches) during 2015-16 and 2016-17 (Mean of two years)

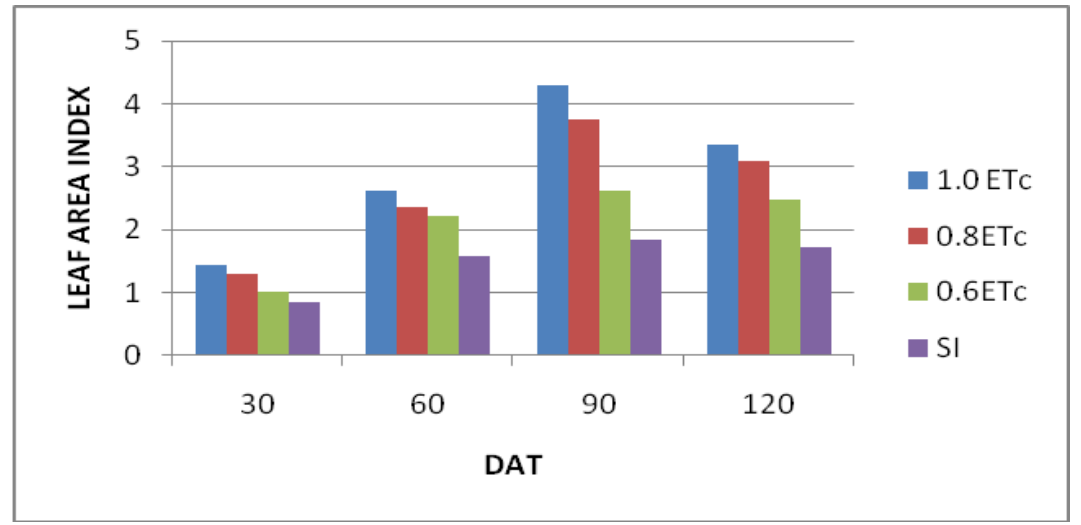

Fig.2 Temporal changes in leaf area index under different mulch managements (Values presented in figure are averaged over irrigation regimes) during 2015-16 and 2016-17 (Mean of two years)

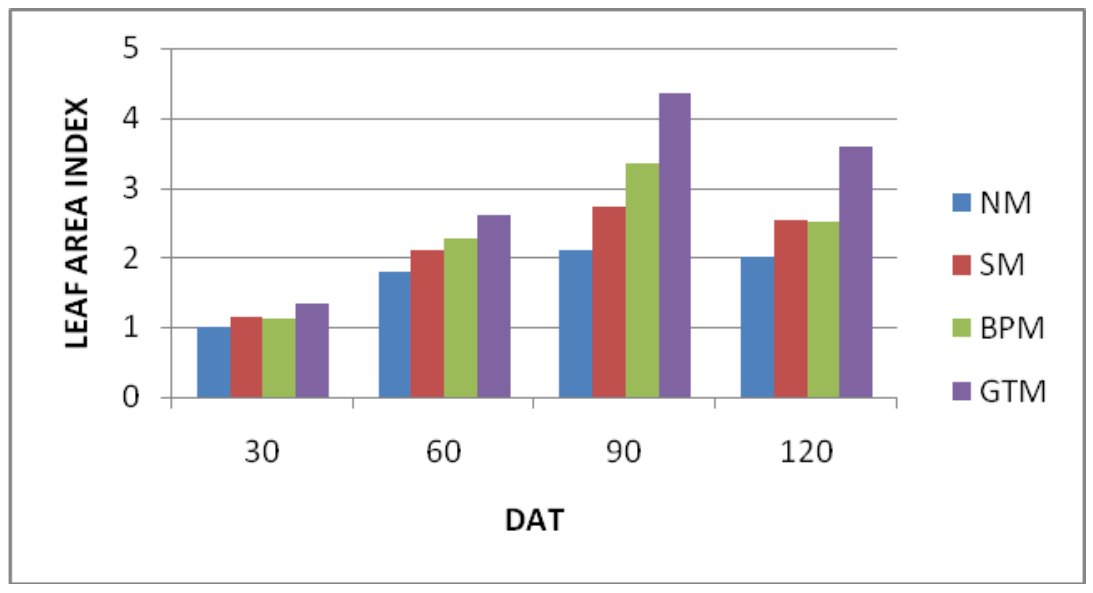

Fig.3 Temporal changes in fruit yield (q/ha) under varying irrigation regimes (Values presented in figure are averaged over mulches) during 2015-16 and 2016-17 (Mean of two years)

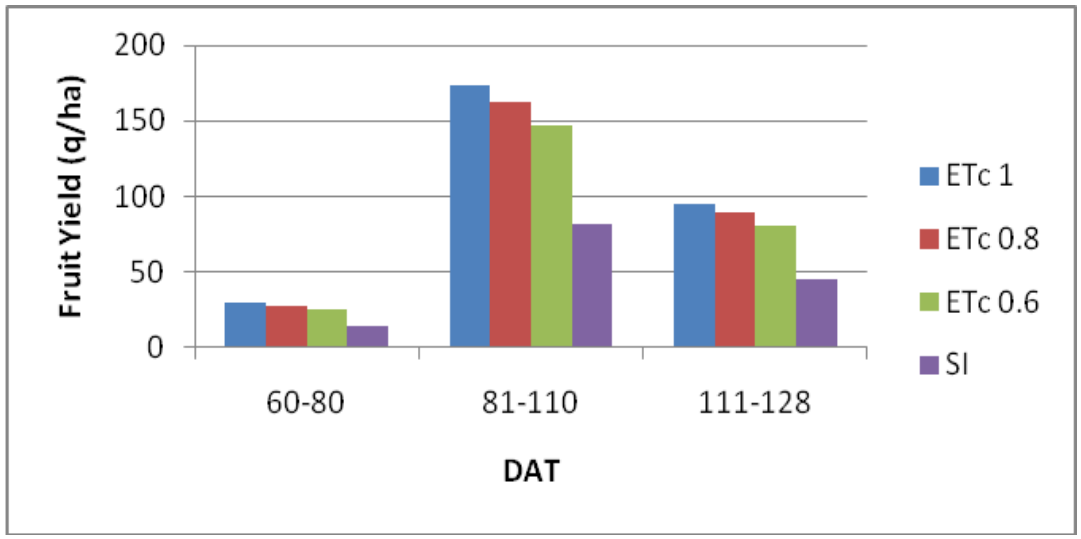


Fig.4 Temporal changes in fruit yield (q/ha) under different mulch managements (Values presented in figure are averaged over irrigation regimes) during 2015-16 and 2016-17 (Mean of two years)

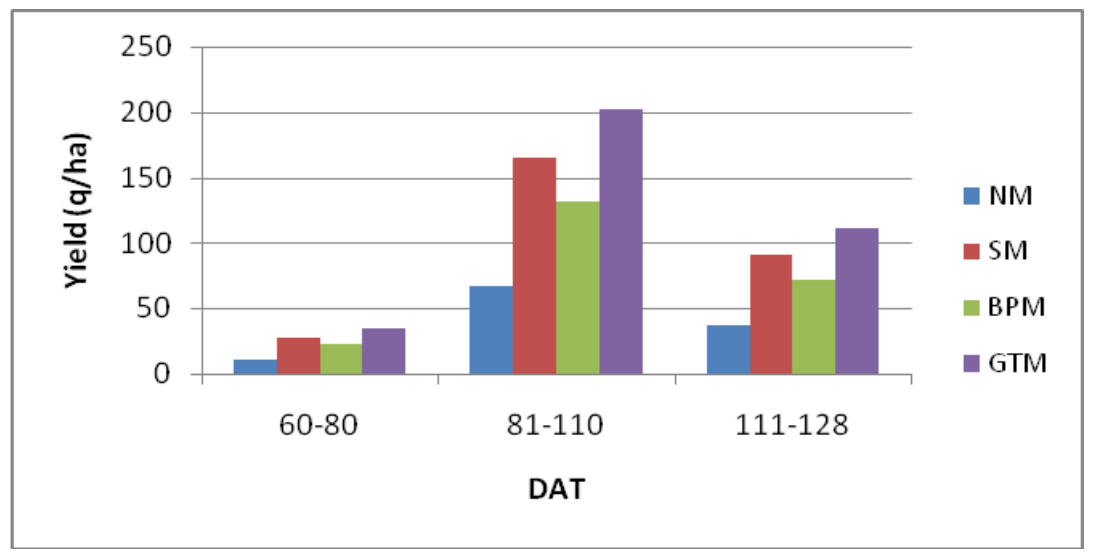

Fig.5 Relationship between LAI and fruit yield (q/ha) during first plucking (60-80 DAT) period during 2015-16 and 2016-17 (Mean of two years)

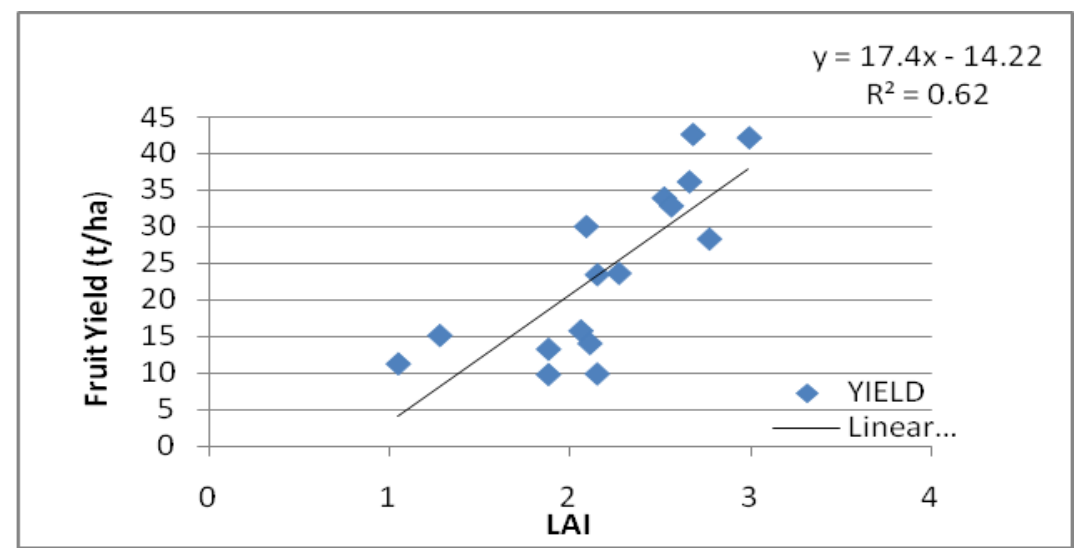

Fig.6 Relationship between Leaf Area Index and fruit yield (q/ha) during first plucking (81-110 DAT) periodduring 2015-16 and 2016-17 (Mean of two years)

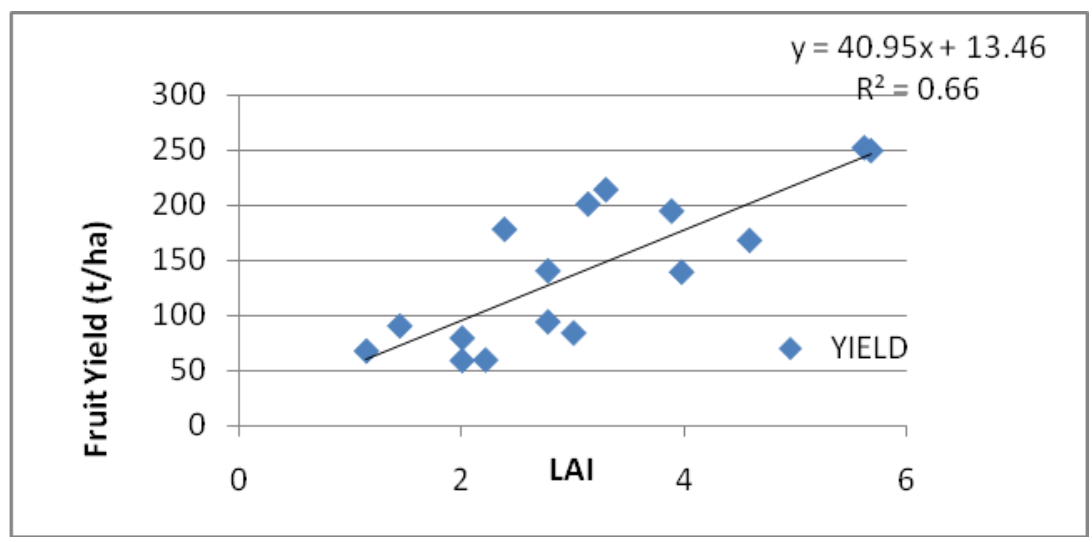


Fig.7 Relationship between Leaf Area Index and fruit yield (q/ha) during first plucking (111-128 DAT) period during 2015-16 and 2016-17 (Mean of two years)

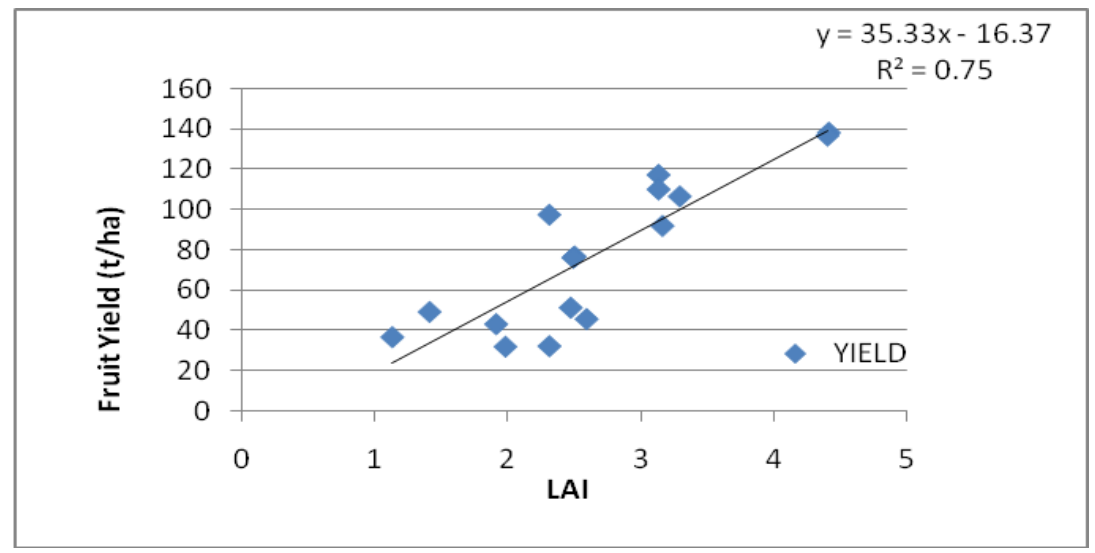

Fig.8 Overall relationship between Leaf Area Index and total fruit yield (q/ha) during 2015-16 and 2016-17 (Mean of two years)

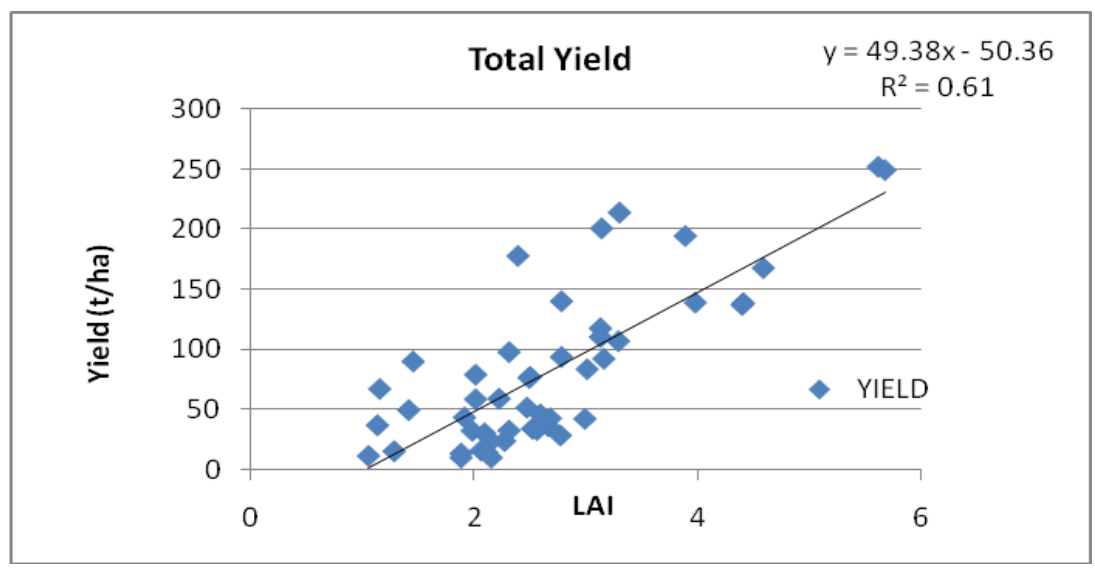

Fig.9 Relationship between total yield (q/ha) and water use efficiency $\left(\mathrm{Kg} \mathrm{m}^{-3}\right)$ under different mulches and varying irrigation regimes during 2015-16 and 2016-17 (Mean of two years)

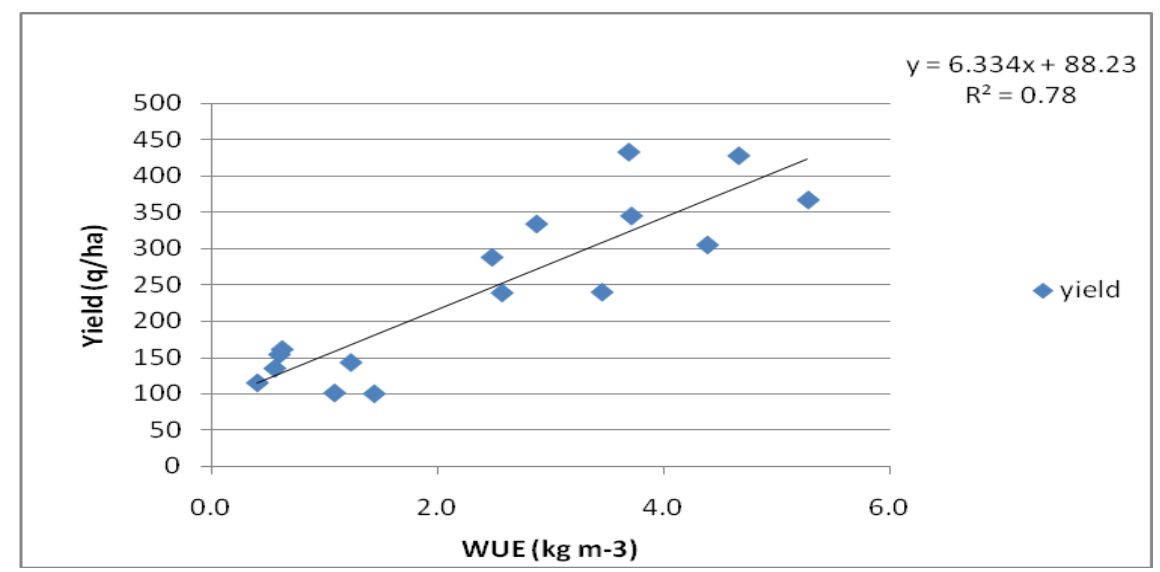


In conclusion fruit yield and LAI was observed to be greatly affected by irrigation and mulch. All the three drip irrigation frequencies resultant 1.5 to 2 times more yield than surface irrigation. Adoption of mulch recorded 2 to 3 folds higher berry yield over no mulched condition. LAI possesses a strong linear relationship with berry yield at each plucking period as well as against the crop. From the present study, it may be concluded that growth of strawberry greatly depends on the irrigation and types of mulches.

\section{Acknowledgements}

I feel unfathomable euphoria to pronounce my heartfelt veneration and gratitude to the Chairman of my advisory committee Dr. Supradip Sarkar, Professor, Department of Agricultural Meteorology and Physics and to Dr. Benukar Biswas, Department of Agronomy, Faculty of Agriculture, Bidhan Chandra KrishiViswavidyalaya for his guidance and invaluable suggestion during the course of my work. I take this privilege to express my profound sense of gratitude and heartfelt thanks to Dr. S. Banerjee, Professor $\&$ Head of the Department and the members of my advisory committee, Prof. M. K. Nanda and Prof. A. Saha, Department of Agricultural Meteorology and Physics, Faculty Of Agriculture, Bidhan Chandra Krishi Viswavidyalaya for their valuable advice and necessary guidance provided during the course of my research work. I also want to thank all the non-teaching staff of the Department of Agricultural Meteorology and Physics, Bidhan Chandra Krishi Vishwavidyalaya, for extending their full cooperation and support.

\section{References}

Allen, G.R., Pereira, S.L., Raes,D., Smith, M. 1998. Crop evapotranspiration Guidelines for computing crop water requirements - FAO Irrigation and drainage paper 56.

Bafna, A.M., Daftardar, S.Y., Khade, K.K., Patel, P.V., Dhotre, R.S. 1993. Utilization of nitrogen and water by tomato under drip irrigation system. J. Water Manage. 1, 1-5.

Childers, N.F., Morris, J.R., Sibbett, G.S. 1995. Modern Fruit Science. Hort. Pub., Gainesville, FL.

Gornat, B., Goldberg, D., Asher, Ben J. 1973. The physiological effect of water quality and method of application on tomato, cucumber and pepper. J. Am. Soc. Hortic. Sci. 98, 202-205.

Huang, Y., Chen, L., Fu, B., Huang, Z., Gong, J., 2004. The wheat yields and wateruse efficiency in the Loess Plateau: straw mulch and irrigation effects. Agric. Water Manage.

Manfrinato, H.A., 1974. Effect of drip irrigation on soil-water plant relationship. In: Second Int. Drip Irrig. Cong., pp. 446-451.

Panse V.G. and Sukhatme, P.V. 1967. Statistical methods for Agriculture workers. Indian council of Agriculture, New Delhi

Raina, J.N., Thakur, B.C., Verma, M.L. 1999. Effect of drip irrigation and polyethylenebmulch on yield, quality and water-use efficiency of tomato. Indian J. Agric. Sci.b 60 (6): 430-433.

Second Int. Drip Irrig. Cong., pp. 446-451.

Singh, S., Singh, A., Singh, V.P., Singh, S., Singh, A. 1999. Use of dust mulch and antitransparent for improving water use efficiency of menthol mint. J. Med. Aromat. Plant Sci. 21, 29-33.

Tekinel, D., Kanber, R., Onder, S., Baytorun, N., Bastug, R., Rydzewsjd, J. R. and Ward, C. F. 1989. The effect of trickle and conventional irrigation method on some crops, yield and water use efficiency under Cukurova conditions. Irrigation Theory and Practice. 641- 
651.

Verma, M.L., Acharya, C.L. 1996. Waster stress indices of wheat in relation to soil water conservation practices and nitrogen. J. Indian Soc. Soil Sci. 44, $368-375$.
Watson, D. J. 1947. Comparative physiological studies on the growth of field crops. I. Variation in net assimilation rate and leaf area between species and varieties and within and between years. Ann. Bot., N.S., II, 41.

\section{How to cite this article:}

Sushanta Sarkar and Supradip Sarkar. 2020. Impact of Irrigation and Mulch on Leaf Area Index, Yield and Water use Efficiency of Strawberry under Polyhouse. Int.J.Curr.Microbiol.App.Sci. 9(02): 864-877. doi: https://doi.org/10.20546/ijcmas.2020.902.104 